Гоблик В.В., доктор економічних наук, дочент, периий проректор Мукачівського державного університету (м. Мукачево, Україна)

\title{
МЕХАНІЗМИ СТАНОВЛЕННЯ ЗОВНІШНЬОЕКОНОМІЧНИХ ЗВ'ЯЗКІВ У ТРАНСКОРДОННИХ РЕГІОНАХ В УМОВАХ ЄВРОПЕЙСЬКОЇ ІНТЕГРАЦІЇ УКРАЇНИ
}

Стаття присвячена важливому теоретико-методичному дослідженню проблематики розвитку транскордонних регіонів, сформованих за участю прикордонних територій держав - членів СС, зокрема в частині активізаиіі зовнішньоекономічної діяльності. Важливим теоретичним $i$ практичним результатом дослідження є проведення класифікації механізмів активізачії зовнішньоекономічної діяльності між прикордонними регіонами України та крайнами - членами Європейського Союзу, яка базується на врахуванні способу впливу на інвестиційне та торговельно-економічне співробітництво. Виокремлено єврорегіональний, преференційний, прикордонно-торговельний, трудоміграиійний, іноваиійний та маркетинговий механізми, використання яких сприяс конвергениії транскордонних регіонів. Запропоновано заходи для підвищення конкурентоздатності регіону, розвитку регіональної економіки Украӥни.

Ключові слова: єврорегіон, конкурентоздатність, Європейський Союз, конкуренція.

This article focuses on important theoretical and methodological research issues of cross-border regions formed with the border areas of EU State Members, particularly in the part of the activation of foreign economic activity. An important theoretical and practical research is carrying out the classification of the mechanisms activation of foreign trade activities between the border regions of Ukraine and countries of the European Union, based on consideration of the impact on the way of investment, trade and economic cooperation. The author single out: Euro-regional, preferential, border-trade, labour and migration, and innovative marketing mechanisms, the use of which contributes to the convergence of transboundary regions. The methods of improving the competitiveness of the region, development of Ukraine's regional economy are proposed.

Keywords: Euro region, competitiveness, European Union, competition.

Набутий країнами $Є \mathrm{C}$ досвід функціонування та організаційноінституційного забезпечення транскордонних регіонів може активно використовуватись на сучасному етапі європейської інтеграції України. Насамперед це стосується адаптації на вітчизняному грунті нових форм і методів розвитку транскордонного співробітництва 3 метою диверсифікації 
зовнішньоекономічної діяльності в межах транскордонних регіонів, створених за участю нашої держави.

Протягом періоду державної незалежності України в межах транскордонних регіонів, сформованих на кордоні з СС, відбувалося постійне становлення та розвиток окремих структуротворчих елементів, у тому числі спрямоване на активізацію зовнішньоекономічної діяльності. Насамперед це стосується розвитку елементів інституційного середовища, удосконалення інфраструктури, поліпшення якості людського капіталу та формування основ транскордонного бізнесу.

Водночас багато проблем, пов'язаних із повноцінним функціонуванням транскордонних регіонів на західному кордоні України, залишаються поки що не вирішеними. Насамперед це стосується розвитку транскордонних ринків, налагодження сучасних методів ведення транскордонного бізнесу, впливу на транскордонну діяльність місцевих громад, налагодження інформаційного супроводу транскордонної діяльності тощо. Крім того, недостатнім є рівень використання в Україні нових форм транскордонної співпраці, зокрема транскордонних кластерів, транскордонних партнерств i транскордонних промислових зон.

Більшість окреслених проблем пов’язані 3 характером становлення та функціонування транскордонних регіонів на кордоні України 3 державами ЄC, а також специфікою еволюції зовнішньоекономічної діяльності в їхніх межах упродовж останніх двадцяти років.

Формування інституційних основ розвитку транскордонного співробітництва України та активізація зовнішньоекономічної діяльності регіонів нашої держави у контексті європейської інтеграції відбувається вже з самого початку здобуття Україною незалежності у 1991 р.

Так, на початку 90-х років минулого століття в західних регіонах нашої держави виникли перші ініціативи щодо формування єврорегіонів. Вони були зумовлені прагненням місцевої влади та регіональних еліт перевести транскордонну співпрацю, яка до цього здійснювалася переважно в епізодичному режимі та значною мірою спорадично, у системну площину. Ключовими мотивами для активізації транскордонного співробітництва за допомогою єврорегіонів слід вважати:

- усвідомлене бажання керівників регіональних органів влади та органів місцевого самоврядування прикордонних територій України інституціоналізувати двостороннє співробітництво зі своїми партнерами 3 країн Центральної та Східної Свропи для більш повного використання потенційних переваг просторового розташування відповідних територій;

- зацікавленість представників громадських організацій, наукових кіл та інших контактних аудиторій в отриманні доступу до фінансових ресурсів, що виділяються за програмами технічної допомоги $Є C$ на реалізацію інфраструктурних проектів; 
- намагання перевести основну частину транскордонних ініціатив 3 гуманітарної площини, яка домінувала в соціалістичний період, у русло економічних взаємозв'язків, пов'язаних зі зростанням обсягів експорту та імпорту товарів і послуг, залученням іноземних інвестицій, розвитком транспортної інфраструктури, а також іншими напрямами активізації транскордонного бізнесу, що тягне за собою зростання економічного потенціалу прикордонних територій та збільшення обсягів фінансових надходжень до бюджетів різних рівнів;

- прагнення мешканців прикордонних територій отримати кращий та більш повний доступ на прикордонні ринки сусідніх держав, у тому числі через розвиток інфраструктури та інших системотворчих елементів транскордонних ринків, 3 метою вирішення власних соціальних та господарських проблем за рахунок інтенсифікації прикордонної торгівлі, посилення трудової міграції, розширення сфери діяльності транскордонного бізнесу тощо).

Крім того, єврорегіональна співпраця, яка є одним з основних елементів стратегії європейської інтеграції ЄС, забезпечує ставлення до відповідних регіонів з боку СС як до певної форми їхнього залучення до складу структур об’єднаної Європи. Відтак єврорегіональні ініціативи отримали свою підтримку і на найвищому державному рівні в Україні, оскільки виконували роль своєрідного політичного важеля в реалізації євроінтеграційних прагнень нашої держави [1].

Перший єврорегіон із залученням прикордонних територій України Карпатський - було створено при активній участі центральних органів державної влади. Зокрема, саме міністри закордонних справ трьох держав: України, Угорщини та Польщі, у лютому 1993 р. в угорському місті Дебрецен підписали угоду про його заснування. До складу цього єврорегіону увійшли прикордонні території України, Польщі, Словаччини, Угорщини та Румунії. Загальна площа єврорегіону становить близько 154 тис. км², а на його території мешкає майже 16 млн. осіб. Головним завданням Карпатського єврорегіону було визначено сприяння об'єднанню людей, які живуть у зоні Карпат, іхньому співробітництву в галузях науки, культури, освіти, торгівлі, туризму та економіки [2].

Таким чином, перший єврорегіон, створений за участю прикордонних територій України, не був типовим єврорегіональним утворенням як за характером свого заснування, так $\mathrm{i}$ за та специфікою подальшого становлення і розвитку. Це дає підстави стверджувати, що рівень впливу єврорегіонів на транскордонну співпрацю між адміністративнотериторіальними одиницями України та суміжними територіями сусідніх держав Європи, що входять до їхнього складу, $\epsilon$ дещо відмінним від загальноєвропейської практики, особливо порівняно 3 єврорегіонами, що функціонують на внутрішніх кордонах ЄС. 
Насамперед це стосується основних напрямів і форм транскордонної активності у межах єврорегіонів, значна частина якої спрямовується на подолання різниці в рівнях життя мешканців прикордонних регіонів України та сусідніх $з$ нею держав Європи. Крім того, після входження Польщі, Словаччини, Угорщини та Румунії до СС, єврорегіони «Карпати» і «Буг» взяли на себе також роль своєрідного регіонального політичного буфера, орієнтованого на нівелювання низки негативних наслідків, пов'язаних 3 ускладненням режиму перетину західного кордону нашої держави.

По-друге, організаційно-управлінська специфіка функціонування єврорегіонів, створених за участю прикордонних територій України, певною мірою відрізняється від загальноприйнятої європейської практики. Зокрема, вітчизняні науковці відзначають, що у засіданнях керівних органів єврорегіонів бере участь, як правило, вище обласне керівництво, а на рівень місцевих громад діяльність майже не опускається, спостерігається недостатня фахова підготовка управлінських кадрів, часта зміна керівництва, значний суб'єктивний фактор у прийнятті рішень тощо [3]. Як наслідок, єврорегіони, що діють на кордоні між Україною та сучасними державами $\mathrm{CC}$, $\epsilon$ організаційно значно більш розконцентрованими та функціонально складнішими, ніж їхні західноєвропейські аналоги.

По-третє, ефективність та масштабність реалізовуваних на території нашої держави єврорегіональних програм поступається за більшістю показників аналогічним параметрам функціонування тих єврорегіонів, що діють на внутрішніх кордонах $\mathrm{CC}$, а також тих, які утворювалися свого часу на зовнішніх кордонах $Є С$ із включенням прикордонних територій країн кандидатів на членство (Австрії, Польщі, Чехії, Угорщини тощо).

По-четверте, роль єврорегіонів у системі структуротворчих елементів українсько-польського, українсько-словацького, українсько-угорського та українсько-румунського транскордонних регіонів є значно вагомішою від тієї ролі, що зазвичай виконують єврорегіони на внутрішніх кордонах $Є С$. Насамперед це стосується їхнього впливу на транскордонний бізнес та активізацію співпраці в соціально-економічній та політичній площинах.

По-п'яте, єврорегіони, створені за участю прикордонних областей на західному кордоні України, в силу специфіки свого функціонування та особливостей розвитку геополітичної та геоекономічної ситуації у відповідних транскордонних регіонах, значно сприяють активізації зовнішньоекономічної діяльності в їхніх межах. Це стосується стимулювання зовнішньоторговельного обміну між українськими та закордонними підприємцями, що ведуть свою діяльність у межах тих транскордонних регіонів, на території яких діють зазначені єврорегіональні об'єднання. Адже завдяки більш активному спілкуванню керівників місцевих органів влади в умовах функціонування єврорегіонів відбувається диверсифікація ділових контактів та зростання взаємного рівня довіри між господарськими елітами суміжних прикордонних регіонів України та сусідніх із нею держав. Крім 
того, на різноманітних регіональних заходах (форумах, конференціях, виставках), що проводяться під егідою єврорегіонів, упродовж усього періоду їхнього існування відбувався постійний обмін ідеями та пропозиціями щодо можливих напрямів i пріоритетів реалізації спільних інвестиційних проектів. Завдяки цьому функціонування єврорегіонів активно сприяло розвитку інвестиційно-економічного співробітництва в межах відповідних транскордонних регіонів.

Виходячи 3 вищесказаного, можна констатувати, що Карпатський єврорегіон, так само, як і єврорегіон «Буг», який був створений у вересні 1995 року і включає прикордонні території України, Польщі та Білорусі, не слід розглядати як прості транскордонні об'єднання єврорегіонального типу. Роль цих єврорегіонів є значно ширшою, ніж зазвичай прийнято вважати. Вони виконують також функції адміністративно-управлінської координації, інституційно-просторової інтеграції та організаційної ідентифікації окремих елементів відповідних транскордонних регіонів на тлі наявної значної диференціації в економічному устрої України та сусідніх держав, території яких входять до складу цих єврорегіонів. До того ж кожен із них, на різних етапах свого існування, забезпечував послідовне проходження транскордонними регіонами відповідних стадій моделі свого формування: 1) просторово-матеріальну структуризацію регіону; 2) розвиток регіональної свідомості; 3) інституціональний розвиток регіону 4) стабілізацію регіону[4]. Варто також звернути увагу i на те, що в методологічному аспекті єврорегіони «Карпати» та «Буг» взяли на себе виконання низки тих функцій, які не $\epsilon$ типовими для класичних єврорегіонів. Зокрема, вітчизняні дослідники вважають, що необхідною умовою ефективного функціонування єврорегіонів $є$ наявність чітко визначених спільних інтересів їх членів, зокрема, у розв'язанні таких проблем, як зміцнення взаємної довіри та безпеки; вироблення спільної стратегії охорони довкілля, використання спільних водних ресурсів; вироблення спільної стратегії просторового розвитку транскордонного регіону; спільного використання енергетичних ресурсів; узгодження розвитку прикордонної інфраструктури; розвитку спільної підприємницької та інформаційної інфраструктури; ефективного використання людських ресурсів шляхом взаємного визнання їх професійної кваліфікації, створення єдиного ринку праці тощо [5].

Водночас єврорегіони, створені за участю прикордонних територій на західному кордоні України, у силу специфіки свого формування та функціонування, значної кількості учасників та кола їхніх інтересів, а також через низку політичних чинників впливу, далеко не завжди відповідали вищезазначеним критеріям.

По-перше, їхня діяльність лише зрідка спрямовувалась на досягнення чітких та однозначних цілей для задоволення узгоджених інтересів регіонівучасників. Натомість доволі часто між ними спостерігалася конкуренція, яка 
виявлялася у боротьбі за фінансові та інші ресурси не лише на міждержавному рівні, але й серед прикордонних регіонів однієї держави. По-друге, в межах зазначених єврорегіонів так i не вдалося досягти формування спільних стратегій просторового розвитку для відповідних транскордонних регіонів.

По-третє, до цього часу на українсько-польському, українськоугорському, українсько-словацькому та українсько-румунському кордонах спостерігаються разючі відмінності в рівні розвитку прикордонної інфраструктури, які, за логікою функціонування єврорегіонів, вже давно б мали стертися. Це ж саме стосується підприємницької та інформаційної інфраструктури.

По-четверте, ефективне використання людських ресурсів шляхом взаємного визнання їх професійної кваліфікації в межах діючих єврорегіонів унеможливлюється через низку об'єктивних і суб'єктивних причин, а створення єдиного ринку праці виявляється відверто непосильним завданням з огляду на однозначну недостатність наявних у єврорегіонів організаційних та інституційних важелів впливу.

Таким чином, єврорегіони, сформовані на кордоні між Україною та СС, відіграють особливу роль у становленні та розвитку відповідних транскордонних регіонів. 3 одного боку, характер їхнього функціонування не дозволяє забезпечувати виконання всіх тих завдань, що покладаються на єврорегіони в державах ЄС. Проте 3 іншого, єврорегіони, до складу яких входять прикордонні території України, беруть на себе частину функцій 3 поглиблення зовнішньоекономічної діяльності в межах відповідних транскордонних регіонів, що дозволяє розглядати їх як важливий елемент інституціоналізації зовнішньоекономічних зв'язків у цих транскордонних регіонах в умовах європейської інтеграції України.

Наприклад, пріоритетними напрямами розвитку транскордонного співробітництва у Карпатському регіоні до 2011 р., зумовленими діяльністю єврорегіону «Карпати», були визначені: економіка, інфраструктура, природа та розвиток сільської місцевості, туризм, а також соціальна та культурна інтеграція [6]. 3 цього переліку лише останній пункт безпосередньо не пов'язаний 3 прямим впливом на активізацію зовнішньоекономічної діяльності у транскордонному регіоні Карпат, хоча опосередковано, через підвищення якості життя населення та зростання споживчого попиту на товари і послуги, соціальна та культурна інтеграція також стимулює зовнішньоекономічний обмін товарами і послугами.

Все зазначене дозволяє стверджувати про наявність єврорегіонального механізму становлення зовнішньоекономічних зв'язків у транскордонних регіонах України, а також окреслити сферу дії цього механізму в умовах європейської інтеграції нашої держави (рис. 1).

На особливу увагу заслуговує інституційна роль єврорегіонів у контексті розвитку соціально-економічного співробітництва прикордонних регіонів нашої 
держави із сусідніми територіями країн ЄС. Зокрема, дослідники відзначають: «Необхідно підкреслити, що можливості, які надаються в рамках програм та ініціатив ЄС, спрямовані безпосередньо на розвиток прямої співпраці між територіальними громадами або владами по обидва боки державного кордону, незалежно від того, чи входять ці території до складу єврорегіонів, чи ні.

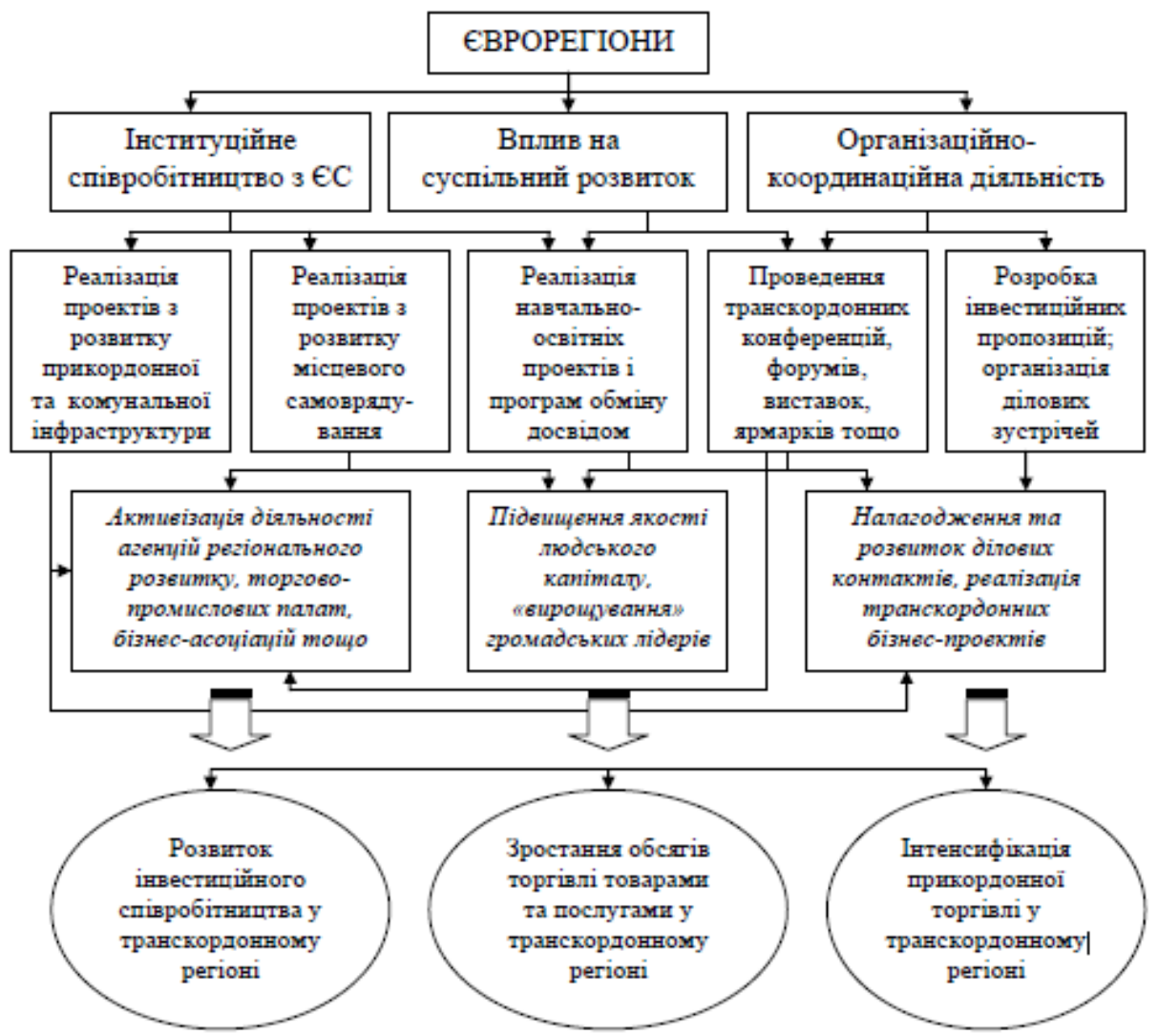

Рис. 1. Механізм становлення та розвитку зовнішньоекономічних зв'язків у транскордонних регіонах, обумовлений функиіонуванням єврорегіонів (авторська розробка)

Але мусимо додати одне застереження: хоча формально членство прикордонних регіонів у єврорегіонах не надає переваг при селекції проектів транскордонного співробітництва для подальшого фінансування 3 коштів цих програм та ініціатив, однак існуючий досвід демонструє, що спільні проекти, які мають здійснюватися в рамках єврорегіонів, мають кращі шанси на отримання грантів від Європейської Комісії» [7]. В цьому сенсі єврорегіональний механізм становлення та розвитку зовнішньоекономічних зв'язків у транскордонних регіонах, до яких входять прикордонні території України, відзначається певними особливими рисами, не притаманними іншим аналогічним механізмам.

Крім того, єврорегіони виступають дійовим важелем зміцнення сусідських відносин та реалізації спільних зусиль у напрямі інвестиційного розвитку транскордонних регіонів. Наприклад, однією 3 особливостей єврорегіону «Буг» $є$ спрямування спільних зусиль органів місцевої влади у 
Волинській області України, Люблінському воєводстві Польщі та Брестській області Білорусі на зростання інвестицій у пріоритетні напрями діяльності та збільшення експортно-імпортних операцій між державами [8].

Поряд 3 єврорегіонами важливим механізмом становлення зовнішньоекономічних зв'язків у транскордонних регіонах в умовах європейської інтеграції України слід визнати створення різного роду преференційних економічних режимів. Такі режими покликані сприяти активізації регіонального розвитку прикордонних територій нашої держави, у тому числі за рахунок поглиблення і диверсифікації зовнішньоекономічних зв'язків із прикордонними регіонами сусідніх держав Європи.

Основними преференційними економічними режимами, які використовувалися в Україні 3 метою господарського розвитку прикордонних регіонів та активізації їх зовнішньоекономічної діяльності, можна вважати створення спеціальних економічних зон i територій пріоритетного розвитку. Водночас у світовій практиці в цьому контексті також активно використовуються безмитні зони, транскордонні технопарки та бізнес-інкубатори, елементи яких упродовж останніх двадцяти років знайшли своє часткове застосування і в Україні.

Механізм дії преференційних режимів у транскордонних регіонах полягає у стимулюванні іноземного інвестування, освоєння нових технологій та імпорту високотехнологічного обладнання, що веде до розвитку транскордонного бізнесу та диверсифікації транскордонних ринків товарів $\mathrm{i}$ послуг. Як наслідок, відбувається активізація інвестиційного співробітництва у межах транскордонного регіону, а також збільшуються обсяги транскордонної торгівлі товарами і послугами (рис. 2).

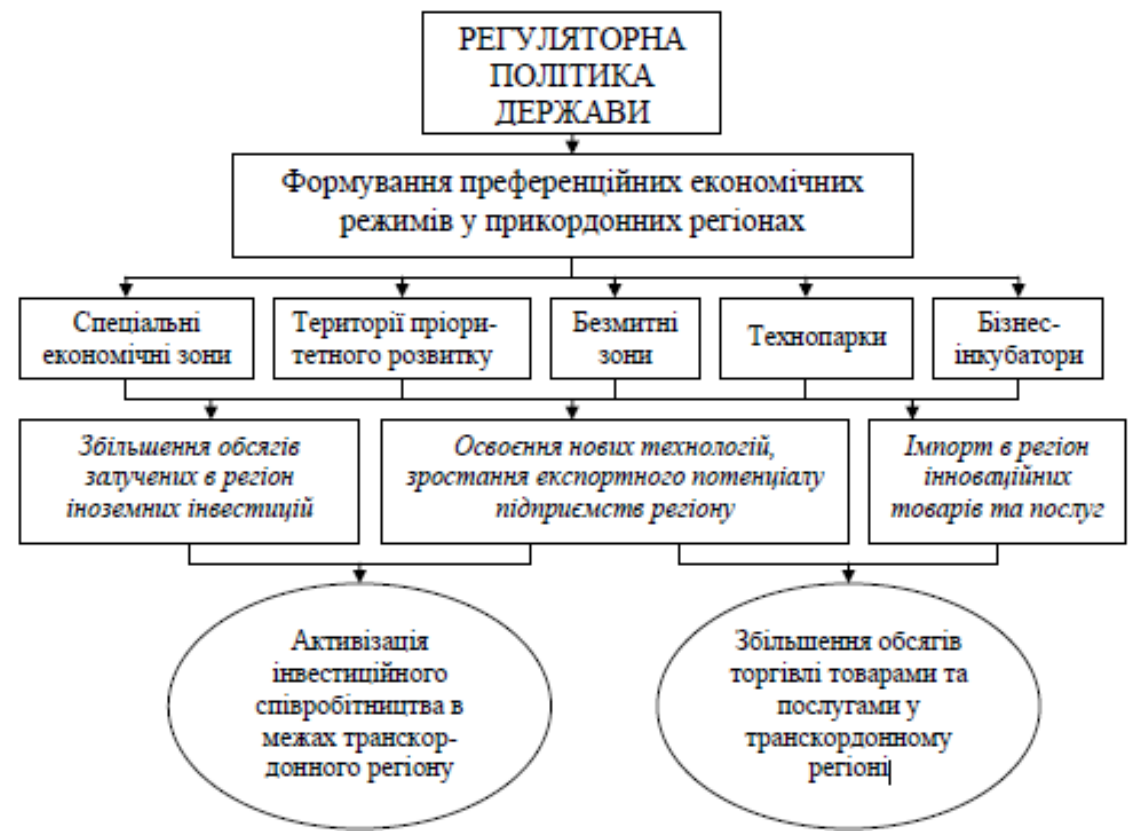

Рис. 2. Алгоритм дї преферениійного механізму становлення та розвитку зовнішньоекономічних зв 'язків у транскордонному регіоні (авторська розробка) 
Основною метою формування преференційних режимів, зокрема спеціальних економічних зон (СЕ3), які діють на території України з середини 1990-х років, крім іншого, було намагання підвищити ефективність функціонування об’єктів комунікаційної інфраструктури портів, митниць тощо. Потужності цих об'єктів на той час явно недовикористовувались, будучи завантаженими на 20- 25\%, що разом із частими змінами в податковій та митній політиці завдавали цим об'єктам великих збитків. За допомогою механізму CE3, а також транскордонних технопарків i технополісів планувалося стимулювати розвиток зовнішньоекономічних зв'язків та забезпечувати соціально-економічне відродження країни в цілому. При цьому складовими регіональних програм розвитку зовнішньоекономічних зв'язків у контексті реалізації преференційного режиму їхньої активізації повинні були стати конкретні проекти (підпрограми): нарощування експортного потенціалу регіонів, створення імпортозаміщуючих виробництв, розвитку науковотехнічного співробітництва, залучення вітчизняних та іноземних інвестицій [9].

На жаль, на практиці механізм преференційних режимів, спрямованих на розвиток зовнішньоекономічної діяльності прикордонних регіонів України, був використаний далеко не повною мірою. Це зумовлювалося як безсистемною практикою його застосування, так i низкою помилок в інституційному та організаційно-технічному забезпеченні функціонування CE3, ТПР і технопарків на території нашої держави. У цьому контексті вітчизняні науковці наголошують: «Якщо за кордоном CE3 формувались як інструмент інтеграції в глобальний економічний простір, а відтак виконували «елітну» функцію, на забезпечення якої держава не шкодувала коштів, то в Україні все було з точністю до навпаки... Українська влада «зекономила» на розвитку виробничої та соціальної інфраструктури, витратах, пов'язаних із пропагуванням своїх СЕ3, розробкою інвестиційних пропозицій, їх презентацією, супроводом інвестиційних проектів тощо. 3 іншого боку, вона отримала «в обмін» на це не надто потужних інвесторів, повільне нарощування інвестиційних можливостей своїх СЕ3, малу фінансову віддачу від реалізації інвестиційних проектів.., а деякі з українських СЕ3, по суті, так по-справжньому і не запрацювали» [3, с.188-189].

Крім того, українська практика запровадження спеціальних економічних режимів стимулювання регіонального розвитку, насамперед СЕ3, не узгоджувалась іще з одним принципом їх ефективного функціонування. Вона суперечила правилу, згідно з яким «тільки органічне поєднання концепції вільних зон 3 державною економічною політикою забезпечує отримання позитивних результатів, сприяє залученню іноземних інвестицій» [10].

Попри це, навіть в умовах недостатньо ефективного застосування преференційних економічних режимів, прикордонні області нашої держави отримали неабиякий поштовх для розвитку зовнішньоекономічних зв'язків у межах відповідних транскордонних регіонів. Зокрема, у цьому зв’язку 
дослідники відзначали, що «якби не було пільгового режиму, не було адекватної та зваженої політики місцевої влади.., то не було б інвестиційних проектів.., не було б робочих місць» [11], а також наголошували на тому, що «процес формування нових зональних утворень не повинен припинятися, а орієнтуватися на проведення локальних експериментів 3 відлагоджування різноманітних економічних методів державного регулювання розвитку інших секторів (галузей) регіонів на основі посилення властивих їм факторів конкурентоспроможності» [12].

До цього слід додати, що саме на територіях СЕЗ і ТПР, створених в українсько-угорсько-словацькому та українсько-польському транскордонних регіонах (СЕЗ «Закарпаття», СЕЗ «Яворів», СЕЗ «Курортополіс Трускавець», ТПР Волинської області) було реалізовано низку інвестиційних проектів із залученням потужних іноземних інвесторів: «Ядзакі» (Японія), «Джебіл» (США), «Фольксваген-Сврокар» (Німеччина), «Кроноспан» (Австрія), «Йоха» (Данія), «Дельфін» (Франція), «Ріксос» (Туреччина), «Церсаніт» і «Снєжка» (Польща) тощо, кожен 3 яких зробив суттєвий внесок у розвиток зовнішньоекономічних зв'язків у межах відповідних транскордонних регіонів.

У роботах закордонних авторів, присвячених проблематиці спеціальних преференційних економічних режимів та дослідженню їхнього впливу на зовнішньоекономічну діяльність регіонів, зазначається також, що продумана система пільг і господарських стимулів спроможна чинити суттєвий сприятливий вплив на розвиток транскордонного бізнесу, зокрема в частині впровадження інноваційних технологій i нарощування експортного потенціалу підприємств. У результаті цього створення СЕЗ та запровадження інших преференційних режимів на території прикордонних регіонів дозволяє запобігати поглибленню кризових тенденцій та створювати нові ресурси для регіонального розвитку [13].

Своєрідним доповненням до економічного впливу механізму преференційних режимів на розвиток зовнішньоекономічних зв'язків у транскордонних регіонах $€$ механізм, сформований на базі розвитку прикордонної торгівлі.

Так само, як і діяльність єврорегіонів, прикордонна торгівля має низку специфічних, притаманних лише їй важелів впливу на активізацію та диверсифікацію зовнішньоекономічних зв'язків у транскордонному регіоні. Насамперед це стосується налагодження безпосередніх ділових контактів на рівні індивідів - мешканців прикордонних територій сусідніх держав та формування на цій основі стабільного інституційного базису здійснення ними підприємницької діяльності в межах транскордонного регіону. Саме завдяки цій особливості прикордонна торгівля відзначається особливою стійкістю щодо змін зовнішнього середовища і може відносно безболісно пристосовуватися як до кризових ситуацій, так і до інноваційного розвитку транскордонного бізнесу. 
Наприклад, після набуття низкою сусідніх з Україною держав членства в $\mathrm{EC}$, що потягнуло за собою суттєві зміни в режимі перетину кордону, а відтак і в умовах ведення прикордонної торгівлі, іiі учасники зуміли відносно швидко адаптуватися до нових правил. 3 цього приводу експерти, зокрема, зауважують: «Наступило те, що економісти називають диверсифікацією. Невидимі зв'язки та контакти дозволяють підібрати такі набори товарів, які роблять обмін вигідним. Домашні умільці - діти, що виросли на цих заробітках, вже допомагають через Інтернет та мобільний зв'язок. Тому відверті комунікації між собою і оточуючими людьми дозволяють їм швидше охоплювати більший масив інформації. Далі розвинутий психологічний підхід та інтуїція дозволяють на основі цього шукати все нові способи заробітку [14].

Таким чином, прикордонна торгівля, яка в більшості випадків розглядається фахівцями 3 макроекономіки та державними функціонерами винятково як примітивний спосіб організації зовнішньоекономічної діяльності на місцевому рівні, сьогодні набуває дедалі нових рис, в тому числі і шляхом адаптації на вітчизняному грунті інноваційних технологій i методів ведення бізнесу.

Крім того, вітчизняні науковці, що спеціалізуються на проблематиці прикордонної торгівлі, наголошують: «Прикордонна торгівля, яка визначається як потік товарів та послуг через міжнародні сухопутні кордони у зоні до тридцяти кілометрів від таких кордонів, відіграє вагому роль у забезпеченні засобів існування людей у прикордонних населених пунктах. Вона збільшує доходи осіб, що беруть участь у такій торгівлі, водночас зміцнюючи місцеве виробництво та стимулюючи надання послуг (наприклад, складських, транспортних, допоміжних послуг на місцевих ринках); забезпечує доходи людям, які працюють на базарах, а також тим, хто займається діяльністю, пов“язаною з базарами та торгівлею; знижує імпортні ціни на товари, які доступні споживачам у прикордонних зонах, i дозволяє експортерам отримувати вигоди від більшої доданої вартості» [15].

Ключовими ланками прикордонно-торговельного механізму становлення та розвитку зовнішньоекономічних зв'язків транскордонного регіону $\epsilon$ : формування торговельно-посередницьких мереж $у$ межах транскордонного регіону, розвиток логістичних систем, орієнтованих на обслуговування прикордонної торговельної діяльності, а також спонтанний вплив на розвиток неформальних інститутів розвитку транскордонного підприємництва та еволюції транскордонних ринків, включаючи розвиток виробничої, транспортної та комунальної інфраструктури (рис. 3). 


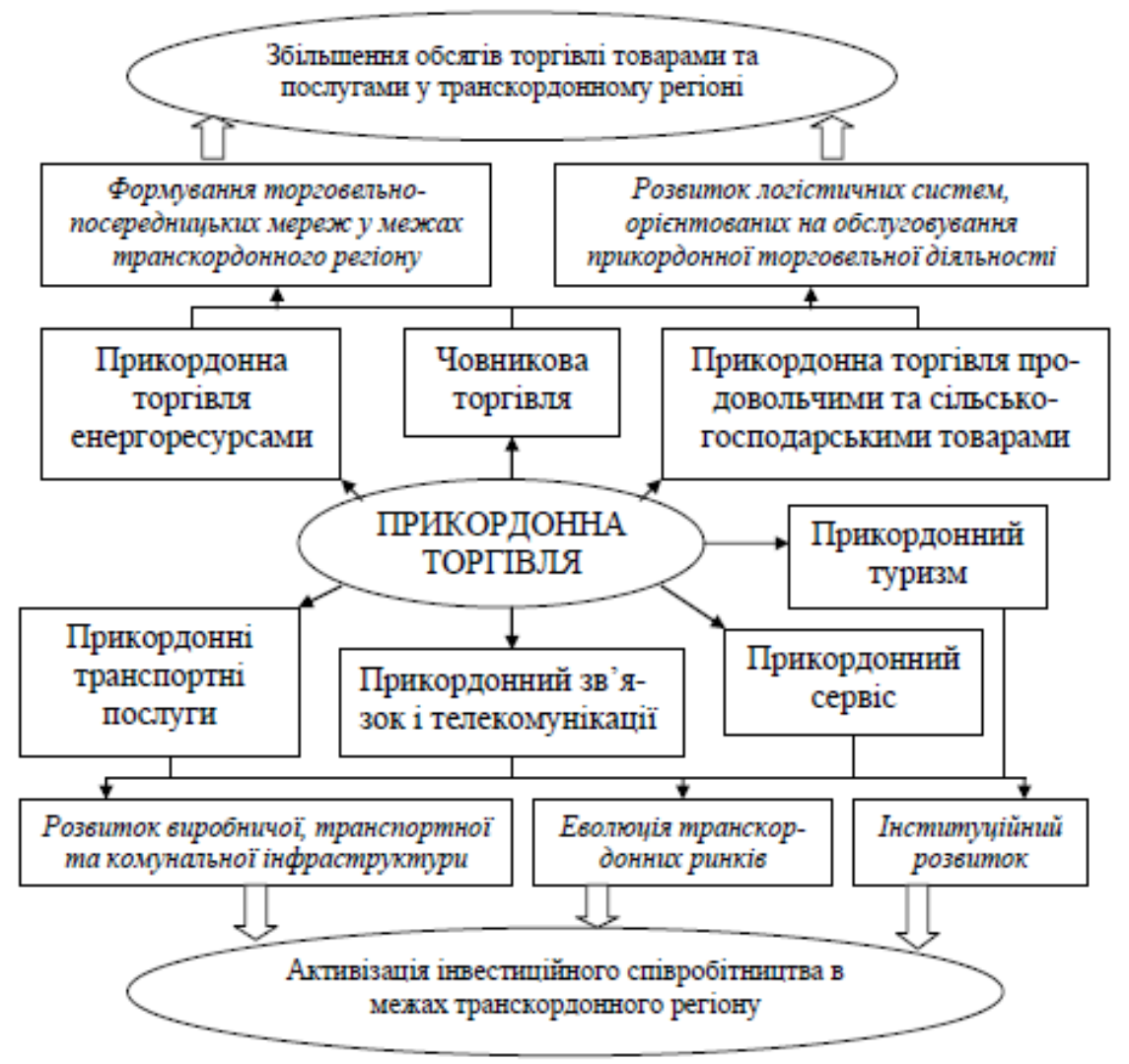

Рис. 3. Прикордонна торгівля в механізмі становлення та розвитку зовнішньоекономічних зв'язків транскордонного регіону (авторська розробка)

Важливою перевагою транскордонної торгівлі як засобу стимулювання зовнішньоекономічної діяльності у межах транскордонного регіону $є$ iї «дешевизна», а саме - відносно низькі витрати на розгортання цього виду підприємницької діяльності та формування елементів інфраструктури бізнесу. 3 цього приводу дослідники зазначають: «Головним спонукаючим мотивом до участі у прикордонної торгівлі виступає невисокий рівень матеріальної забезпеченості громадян... Переважна більшість міграційних переміщень мотивується отриманням доходу шляхом ввозу недорогих товарів споживання з сусідніх країн. Оскільки на товари, які ввозились в державу фізичними особами, довгий час не накладались мита, водночас аналогічні товари, які ввозили в Україну фірми-імпортери, обкладались досить високими ставками мита. Таким чином, більшість осіб, задіяних в прикордонній торгівлі 3 1990-х років, можна віднести до категорії «підприємці мимоволі» [16].

Проведене науковцями Інституту регіональних досліджень НАН України дослідження показує, що 90\% мешканців прикордонних територій Західної України відвідують сусідні держави СС. Дві третини 3 них 
здійснюють там закупівлю товарів. Половина цих товарів закуповується 3 метою подальшого здійснення торгівлі на українському ринку [17].

Попри це, учасники прикордонної торгівлі володіють значним потенціалом для розвитку підприємництва. По-перше, вони отримують європейський досвід підприємницької діяльності. По-друге, більшість із них $\epsilon$ освіченими людьми, які вимушено залишили свою професійну кар'єру, а високий рівень загальної освіти дозволяє їм швидше опанувати нові види діяльності. До того ж, культурна інтеграція у межах транскордонного регіону впливає на якість співробітництва, зокрема в контексті інформаційного розвитку учасників прикордонної торгівлі [16].

Ще одним механізмом становлення та розвитку зовнішньоекономічних зв'язків транскордонного регіону, який спирається на адаптацію в Україні європейського досвіду ведення бізнесу та культурну інтеграцію в європейське суспільство, є міграційно-трудовий.

Трудова міграція як феномен, що поширився в умовах трансформаційної кризи при переході України до ринкової економіки, оцінюється вітчизняними та зарубіжними науковцями далеко не однозначно. На нашу думку, як і будьяке соціально-економічне явище, трудова міграція містить в собі різнорідний потенціал впливу на господарський комплекс регіону. Особливо це стосується такої динамічної сфери, як транскордонне співробітництво.

3 одного боку, виїзд за кодон на тимчасові заробітки мешканців прикордонних регіонів нашої держави загрожує вимиванням частини вітчизняних трудових ресурсів, погіршенням демографічної ситуації всередині держави, дефіцитом кваліфікованого персоналу на українських підприємствах тощо. Однак, 3 іншого погляду, саме трудова міграція забезпечує найвищий рівень суспільної адаптації наших співвітчизників до стандартів життя розвинутих держав Європи, дозволяє набувати їм досвід роботи у ринковому та підприємницькому середовищі держав ЄС, неспівставний за своєю вагомістю з тим, який набувається під час участі у прикордонній торгівлі та інших формах зовнішньоекономічної діяльності у межах транскордонних регіонів, а також забезпечує акумулювання достатніх фінансових ресурсів, що можуть ефективно використовуватись для інвестування в Україні (рис. 4). 


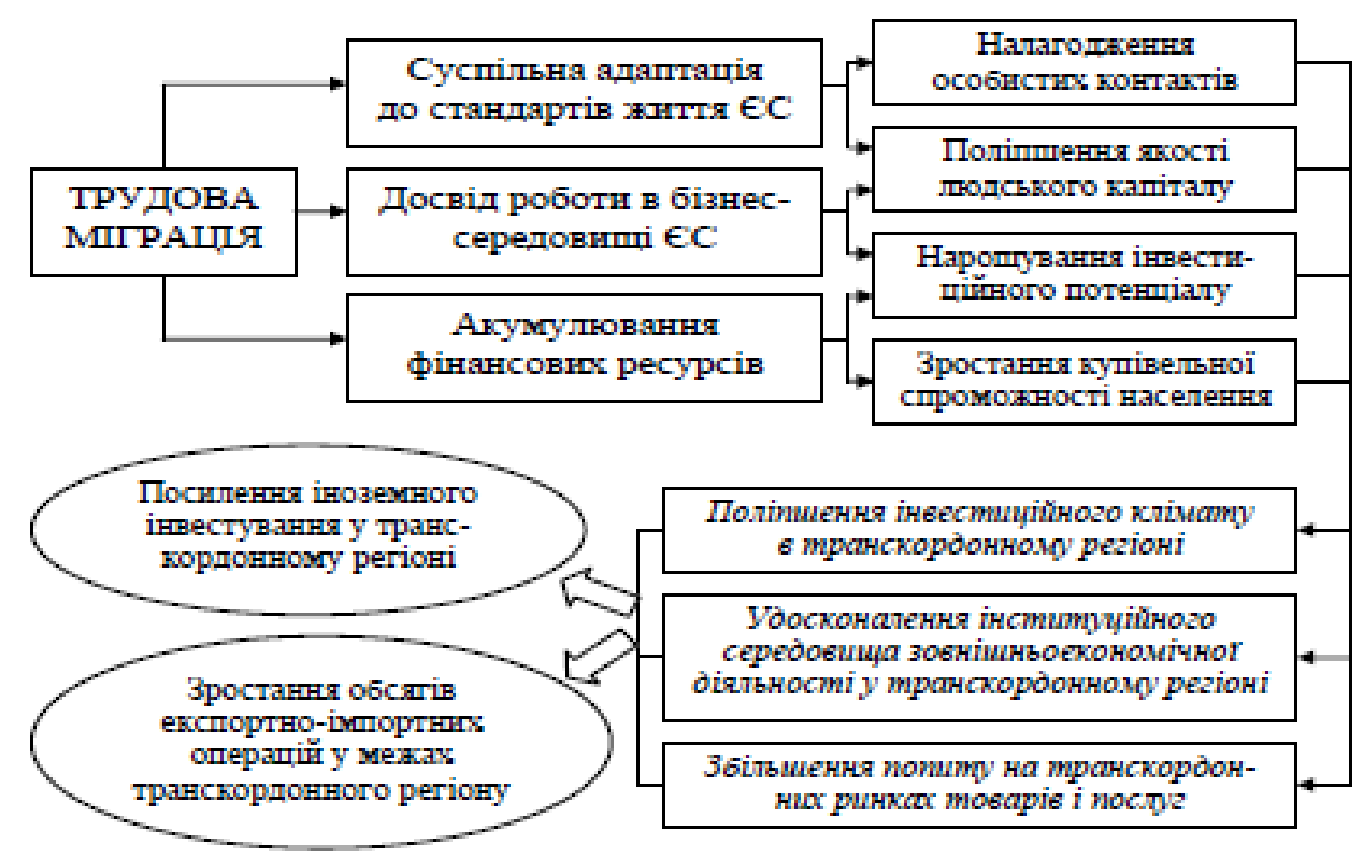

Рис. 4. Трудова міграиія в механізмі становлення та розвитку зовнішньоекономічних зв'язків транскордонного регіону (авторська розробка)

Експерти відзначають, що зовнішня трудова міграція є також джерелом досвіду, знань, міжособистісних контактів, школою бізнесу та ринкової поведінки. Крім цього, значні кошти, які надходять від заробітчан, підвищують платоспроможний попит i таким чином стимулюють виробництво. Вони сприяють розвитку малого бізнесу, прискоренню формування середнього класу [18]. Все це позитивно відображається на активізації зовнішньоекономічних зв'язків у межах транскордонних регіонів, стимулюючи процеси європейської інтеграції нашої держави.

На думку вітчизняних дослідників, «заробітчани, збагачені іноземним досвідом та ознайомлені з їхніми технологіями, також вкладають зароблене у розвиток власної справи. Поки що таких людей небагато, і завдання держави та місцевої влади врешті-решт створити такі умови, щоб їх частка зростала, $\mathrm{i}$ щоб гроші було вигідніше вкладати у виробництво, аніж у торгівлю і сферу послуг, які зараз домінують у малому бізнесі» [19]. Крім того, науковці наголошують: «Інвестиції в людський капітал, зокрема освіту та медицину, поліпшення якості життя не можна не оцінювати позитивно... Забезпечене заробітками трудових мігрантів збільшення попиту на вищу освіту сприяло розвитку галузі. Так, у західних областях України, охоплених масовою еміграцією, зростання кількості вищих навчальних закладів, їх студентів і випускників відбувалося швидшими темпами, ніж у цілому по Україні» [20]. 
Таким чином, трудова міграція мешканців прикордонних територій західних областей нашої держави може розглядатися в контексті функціонування окремого механізму розвитку зовнішньоекономічних зв'язків у межах відповідних транскордонних регіонів. Причому цей механізм, поряд з іншими, які були окреслені вище, не $є$ локальним чи обмеженим у часі своєї дії, як може здатися на перший погляд. Він має значний ресурс збереження власного впливу та стратегічний горизонт подальшої еволюції.

У цьому контексті вітчизняні фахівці звертають увагу на те, що досі ми розглядали трудову міграцію як своєрідну «хворобу Європи», яка не в змозі справитися зі стрімким старінням населення, але вже в найближчому майбутньому Україна має «перехворіти» на цю недугу та навчитися використовувати це на благо своєї економіки. У нас $є$ всі можливості скористатися історичним шансом і не повторити чужих помилок. Адже вже сьогодні є чимала кількість прикладів, коли тисячі вчорашніх трудових мігрантів повертаються в Західну Україну. За накопичені гроші вони відкривають свій малий бізнес: швейні виробництва, готелі, перевезення, «зелений» туризм тощо, розвиваючи тим самим потенціал зовнішньоекономічних зв'язків транскордонного бізнесу [21].

Водночас слід наголосити на тому, що повноцінне використання ресурсу, яким володіє міграційно-трудовий механізм активізації зовнішньоекономічних зв'язків у межах транскордонних регіонів, безпосередньо пов'язане 3 ефективним застосуванням відповідних маркетингових інструментів. Адже без належної популяризації тих можливостей, які з'являються у процесі участі мешканців прикордонних територій України у трудовій міграції, особливо в межах транскордонних регіонів, складно розраховувати на залучення набутого ними досвіду та акумульованих фінансових ресурсів у сферу конкурентоспроможного транскордонного бізнесу.

Більше того, вагоме значення, яке відводиться маркетинговим важелям стимулювання регіонального розвитку в умовах зовнішньоекономічної діяльності прикордонних територій нашої держави, дозволяє виокремлювати маркетинговий механізм становлення та розвитку зовнішньоекономічних зв'язків у транскордонному регіоні. Роль цього механізму дедалі більше зростає в умовах поглиблення європейської інтеграції України, а його ключовими ланками є рекламно-промоційна діяльність, просування спільних інвестиційних продуктів і бізнес-ідей, а також підготовка і проведення спільних спортивних і культурних мега-заходів (рис. 5). 


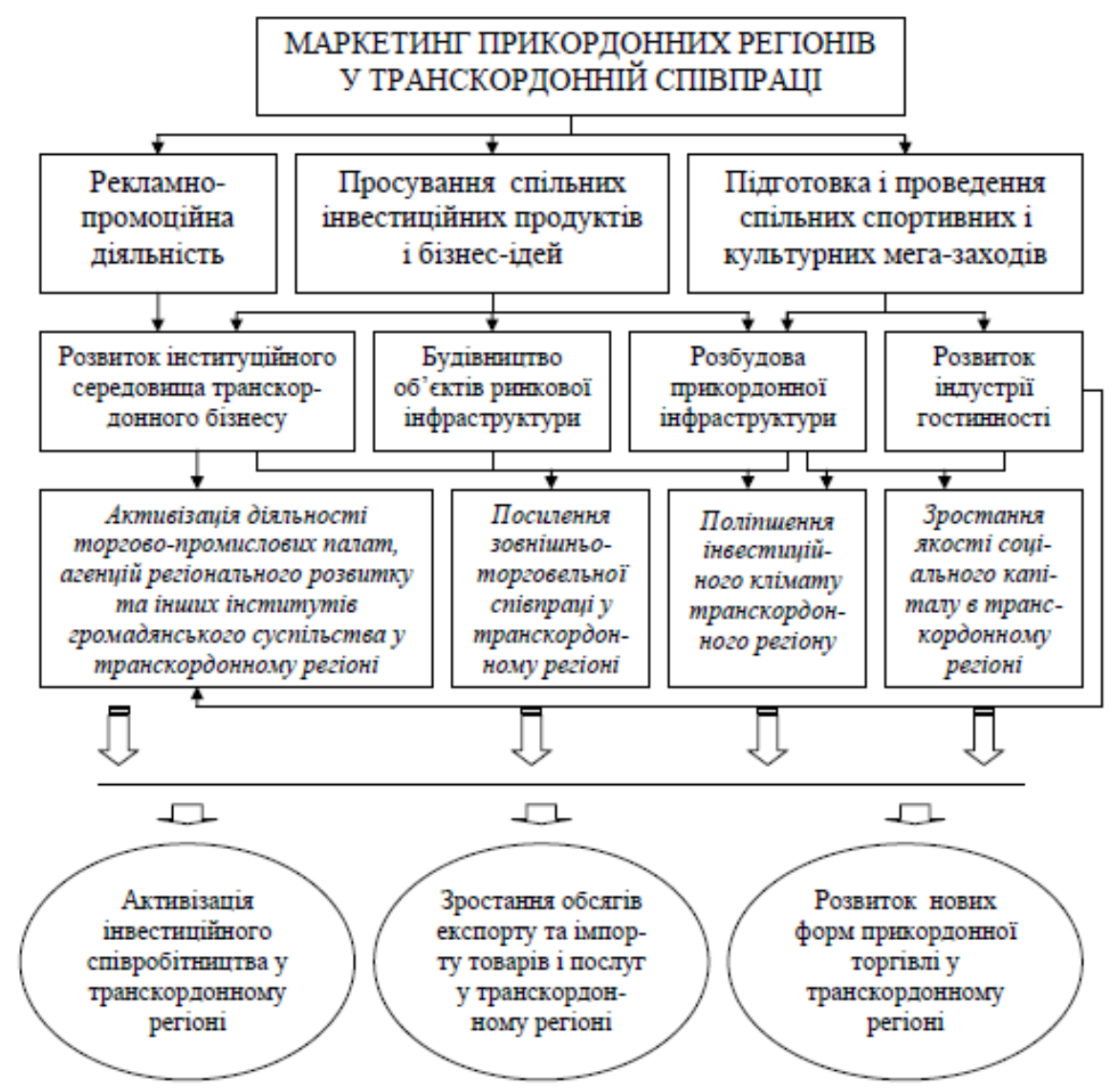

Рис. 5. Маркетинговий інструментарій механізму становлення та розвитку зовнішньоекономічних зв'язків у транскордонному регіоні (авторська розробка)

Як правило, найкращих результатів у соціально- економічному розвитку досягають ті прикордонні території, маркетингові зусилля яких спрямовані на комплексне вирішення нагальних проблем - ефективну реалізацію основних функцій території як місця проживання, відпочинку i господарювання; покращення методів управління та інфраструктури; підвищення конкурентоспроможності розміщених на території підприємств. Усе це досягається в контексті активізації зовнішньоекономічних зв'язків у межах відповідних транскордонних регіонів. Відтак на сучасному етапі економічних реформ в Україні транскордонний маркетинг як складова інструментарію здійснення державної регіональної політики покликаний забезпечувати розвиток та стійке економічне зростання регіонів, їх інтеграцію в загальнодержавний та міжнародний економічний простір, стимулювати зовнішньоекономічну та інноваційну діяльність у транскордонних регіонах [22].

Особливо важливого значення у цьому зв'язку набуває спільне проведення Україною та сусідніми державами ЄС мега-заходів континентального рівня, що сприяє поглибленню європейської інтеграції нашої держави та чинить суттєвий позитивний вплив на розвиток зовнішньоекономічних зв'язків у межах транскордонних регіонів. Яскравим 
підтвердженням цьому є підготовка України та Польщі до Євро-2012, у процесі якої відбулося не лише збільшення обсягів взаємної торгівлі товарами та послугами у прикордонних регіонах обох держав, але й набула подальшого розвитку прикордонна інфраструктура та інституційна співпраця між самоврядними органами прикордонних міст та інших населених пунктів. У перспективі це дає всі підстави очікувати на збільшення обсягів залучення в українсько-польський транскордонний регіон нових інвестиційних ресурсів, у тому числі й на основі реалізації спільних інвестиційних проектів.

Важливим інструментом у системі маркетингу транскордонного регіону $\epsilon$ брендинг території. Наукові дослідження показують, що територія може бути брендована як товар чи послуга, а власне метою брендингу території $\epsilon$ покращення iï привабливості. Брендинг не лише впливає на маркетингову діяльність, але й на цілісний розвиток транскордонного регіону, що зумовлює розвиток різних параметрів його функціонування, включаючи активізацію зовнішньоекономічних зв'язків між окремими підприємствами, інституціями та місцевими громадами загалом. Брендування території приносить ій додаткову привабливість. Саме тому для кожного транскордонного регіону необхідно та цілком можливо віднайти унікальні відмінності, які відрізняють його від інших таких регіонів [23].

Досліджуючи маркетинговий механізм розвитку зовнішньоекономічних зв'язків у транскордонному регіоні, не слід проте ігнорувати суспільнопсихологічні аспекти життєдіяльності транскордонного регіону. Адже часто брендинг території та рекламування окремих iï переваг на міжнародному ринку праці може заохочувати ті види транскордонної активності, які здатні руйнувати традиційний уклад життя окремих громад. Саме тому маркетинговий інструментарій розвитку транскордонних регіонів обов'язково повинен враховувати основні принципи управління регіональними суспільними системами, зокрема [24]:

- об'єктивні тренди розвитку економіки транскордонного регіону (екологізацію, соціалізацію та гуманізацію, інноваційну спрямованість тощо);

- соціально-історичні й геополітичні особливості економіки транскордонного регіону та їі основні принципи (необхідність поєднання ринкових механізмів та заходів державного регулювання соціальноекономічних процесів);

- забезпечення економічної ефективності, соціальної справедливості, захисту інтересів власників і мешканців прикордонних територій;

- появу нових інститутів та інтеграційних i асоційованих форм підприємництва, пов'язаних із різноманіттям форм власності та організації бізнесу;

- особливості регіоналізації економіки, яка обумовлює виникнення специфічних форм управлінсько-господарської діяльності на засадах конкуренції та партнерства; 
- необхідність постійного підвищення рівня кваліфікації кадрового потенціалу та якості людського капіталу транскордонного регіону.

Врахуванню цих та інших особливостей соціально-економічного розвитку транскордонних регіонів на сучасному етапі глобалізації значною мірою сприяє застосування інноваційного механізму розвитку зовнішньоекономічних зв'язків у межах транскордонного регіону. Його суть полягає у використанні інноваційних форм транскордонної співпраці з метою посилення інтегрованості транскордонних ринків та підвищення ефективності транскордонного бізнесу.

Одним 3 найбільш дієвих інструментів сприяння інноваційному розвитку зовнішньоекономічних зв'язків у транскордонному регіоні протягом останнього часу став кластерний підхід.

Характерною особливістю транскордонних кластерів, які в Україні $\epsilon$ поки що мало поширеним явищем, виявляється їхній синергетичний вплив на різні аспекти господарської діяльності у межах транскордонного регіону. Адже, об'єднуючи підприємства та організації різних галузей i видів діяльності з обох боків кордону, транскордонний кластер сприяє зниженню ïх трансакційних витрат в умовах здійснення зовнішньоекономічних операцій. Більше того, у процесі житєдіяльності такого кластера з'являються додаткові стимули щодо приєднання до нього все нових учасників. За рахунок цього зовнішньоекономічна діяльність у межах транскордонного регіону не лише інтенсифікується, але і диверсифікується.

Ефективність формування транскордонних кластерів та рівень їхнього впливу на розвиток зовнішньоекономічних зв'язків у межах транскордонного регіону визначаються низкою ендогенних та екзогенних чинників (табл. 1).

Чинники розвитку транскордонних кластерів в Україні

\begin{tabular}{|c|c|c|}
\hline & Екзогенні & Ендогенні \\
\hline 融 & $\begin{array}{c}\text { Розвиток європейської } \\
\text { кластерної політики; } \\
\text { формування кластерів у сусідніх } \\
\text { країнах } € \text {; } \\
\text { фінансова підтримка з боку } \in \text {; } \\
\text { налвність методологічних } \\
\text { розробок; } \\
\text { наявність фахівців }\end{array}$ & $\begin{array}{c}\text { Зростання інтересу } \\
\text { потенційних учасників; } \\
\text { наявний інтелектуальний і } \\
\text { кадровий ресурс; } \\
\text { науковий доробок } \\
\text { вітчизнних вчених }\end{array}$ \\
\hline 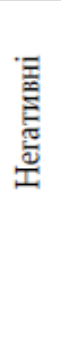 & $\begin{array}{c}\text { Відсутність належного } \\
\text { інституційного та } \\
\text { організаційного забезпечення; } \\
\text { брак мотиваціі у потенційних } \\
\text { закордонних учасників; } \\
\text { політична нестабільність у } \\
\text { взаємовідносинах між Україно } \\
\text { та } \in C\end{array}$ & $\begin{array}{c}\text { Відсутність достатніх } \\
\text { традицій кластерної } \\
\text { співпраці в Україні; } \\
\text { брак інформаціі та } \\
\text { управлінської компетенціі у } \\
\text { представників бізнесу; } \\
\text { дефіцит системних рішень } \\
\text { на рівні регіональних органів } \\
\text { державної вдади }\end{array}$ \\
\hline
\end{tabular}

* Розроблено автором на основі: Демченко В. Особливості формування транскордонних кластерів / В. Демченко // Регіональна економіка. - 2010. - № 3. - С. 182-183. 
Слід відзначити, що сьогодні основними бар'єрами на шляху активізації інноваційного, зокрема кластерного механізму розвитку зовнішньоекономічних зв'язків у межах транскордонних регіонів, до складу яких входять прикордонні території України, $\epsilon$ невідповідність адміністративно-територіального устрою нашої держави та сформованого в ній економічного порядку тим принципам та інституційним нормам, на яких базується економічна політика ЄС. Саме тому дієвість інноваційних форм активізації транскордонної співпраці між прикордонними регіонами України i сусідніх держав ЄC значною мірою залежить від пріоритетів макроекономічної політики та ії наповнення реальним змістом на регіональному рівні.

Слід також зазначити, що використання наявного потенціалу окреслених механізмів розвитку зовнішньоекономічних зв'язків у межах транскордонних регіонів в умовах європейської інтеграції України є одним з важливих засобів адаптації вітчизняної економіки до стандартів СС як на регіональному, так і на загальнодержавному рівні, а відтак і потужним важелем підвищення якості життя та соціального захисту населення.

\section{СПИСОК ВИКОРИСТАНИХ ДЖЕРЕЛ}

1. Роїк Н. Інституційна транскордонна співпраця в контексті розширення ЄС: проблеми та перспективи Карпатського єврорегіону / Н. Роїк [Електронний ресурс]. - Режим доступу: http://www.nbuv.gov.ua/portal/ Soc_Gum/Gileya/2011_43/Gileya43/P29_doc.pdf

2. Еврорегион «Карпаты» [Електронний ресурс]: Режим доступу : http://ru.wikipedia.org/wiki/ Еврорегион_«Карпаты».

3. Борщевський В. Українсько-польське економічне співробітництво в умовах євроінтеграції : монографія / В. Борщевський. - Львів: Аверс, 2007. $328 \mathrm{c}$.

4. Мікула Н.А. Міжтериторіальне та транскордонне співробітництво: монографія / Н.А. Мікула. - Львів: ІРД НАН України, 2004. - С. 185-186.

5. Мікула Н. Сврорегіони: досвід та перспективи / Н. Мікула. -Львів: ІРД НАН України, 2003. - С. 16.

6. Шолох Ю.М. Методологія, організаційно-економічний механізм стратегічного планування в Карпатському регіоні / Ю.М. Шолох // Соціально-економічні проблеми сучасного періоду України. Кластери та конкурентоспроможність прикордонних регіонів: зб. наук. праць. - Вип. 3 (71) / НАН України. Ін-т регіональних досліджень. - Львів, 2008. - С. 348

7. Регіональна політика в країнах Європи: Уроки для України / За ред. С. Максименка. - К.: Логос, 2000. - С. 159-160.

8. Щерба Г.І. Аналіз регіональних особливостей інвестиційної діяльності / Г.І. Щерба, К.В. Повар // Вісник Чернівецького торговельноекономічного інституту. - Чернівці-Луцьк: ЧТЕІ КНТЕУ, 2011. - Вип. II (42), ч. 2. Т. 1. Економічні науки. - С. 49-50. 
9. Долішній М.І. Регіональна соціально-економічна політика (основні засади формування і розвитку) / М.І. Долішній // Регіональна економіка. 1997. - № 2. - С. 20-21

10. Проскурін В. Спеціальні економічні зони та інвестиційний клімат країн Центрально-Східної Європи / В. Проскурін // Економічні есе.- 2005. Вип. 18. - С. 17.

11. Трансформація спеціальних економічних зон України в контексті європейської інтеграції: альтернативні інструменти інвестиційної та регіональної політики : матеріали засідання «круглого столу». - Львів: ЛФ НІСД, 2005. - С. 7.

12. Мокій А.І. Спеціальні (вільні) економічні зони як форма регіонально-секторальної моделі зовнішньоекономічної інтеграції / A.I. Мокій // Регіональна економіка. - 1999. - № 4. - С. 110.

13. Блендовскі М. Спеціальні економічні зони Польщі та їх вплив на місцевий розвиток та інвестиційний клімат / М. Блендовскі // Економічні есе. - 2005. - Вип. 18. - С.22.

14. Губені Ю. Агенти прикордонної торгівлі: про особливості бізнесу західноукраїнських «човників» / Ю. Губені //День. - 2010. - №207-208 (п'ятниця, 12 листопада) [Електронний ресурс]. - Режим доступу : http://www.day.kiev.ua/316269.

15. Мікула Н. Розвиток транскордонного співробітництва України в умовах розширеного СС / Н.Мікула, I. Тимечко [Електронний ресурс]. Режим доступу : http://niss.lviv.ua/analytics/68.htm.

16. Тимечко I. Мотиваційний аналіз суб’єктів прикордонної торгівлі / I. Тимечко [Електронний ресурс]. - Режим доступу : http://www.nbuv.gov.ua/portal/soc_gum/en_etei/2009_6_2/25.pdf.

17. Тимечко I. Вплив прикордонної торгівлі на розвиток малого підприємництва / I. Тимечко // Соціально-економічні проблеми сучасного періоду України. Кластери та конкурентоспроможність прикордонних регіонів: зб. наук. праць. Вип. 3 (71) / НАН України. Ін-т регіональних досліджень. - Львів, 2008. - С. 342.

18. Лех Г.А. Трудова міграція за кордон як спосіб додаткового отримання доходів / Г.А. Лех, І.В. Ангелко [Електронний ресурс]. - Режим доступу. - http://www.nbuv.gov.ua/portal /chem_biol/nvnltu /18_4/127_ Lech_18_4.pdf.

19. Трудова міграція: плюс - для економіки, мінус - для суспільства [Електронний pecypc]. - Режим доступу : http://zik.ua/ua/news $/ 2005 / 01 / 21 / 7450$

20. Малиновська О. А. Трудова міграція: соціальні наслідки та шляхи реагування : Аналітична доповідь / О.А. Малиновська. - К. : НІСД, 2011. C.12.

21. Надрага В. Трудова міграція: виклики для України / В. Надрага // Дзеркало тижня. - 2011. - №5 (11 лютого) [Електронний ресурс]. - Режим 
доступу: http://dt.ua/ECONOMICS/trudova_migratsiya_vikliki_dlya_ukrayini75323.html

22. Жуков С. Вдосконалення механізму транскордонного економічного співробітництва на маркетингових засадах / С. Жуков, I. Чучка [Електронний pecypc]. - Режим доступу : http://www.univ.rzeszow .pl/nauka/konferencje /rl_most/ukr/10-Zukow_szablon-UKR.pdf

23. Кобиляцький O. Актуальність використання інструментів маркетингу території / О. Кобиляцький // Ефективна економіка [Електронний pecypc]. - Режим доступу : http://www.economy.nayka.com.ua/ index.php?operation $=1$ \&iid $=861$

24. Регіональні суспільні системи : [монографія] / НАН України; Інститут регіональних досліджень / Л.К. Семів (відп.ред.). - Л., 2007. - с. 443.

\section{REFERENCES}

1. Royik, N. Instytutsiyna transkordonna spivpratsya $v$ konteksti rozshyrennya YES: problemy ta perspektyvy Karpats'koho yevrorehionu [Institutional Transboundary Cooperation in the Context of EU Enlargement: Problems and Prospects for the Carpathian Euroregion]. Retrieved from: http://www.nbuv.gov.ua/portal/Soc_Gum/Gileya/2011_43/Gileya43/P29_doc.pdf

2. Yevroregion «Karpaty» [Euroregion "Carpathians"]. Retrieved from: http://ru.wikipedia.org/wiki/ Еврорегион_«Карпаты».

3. Borshchevs'kyy, V. (2007). Ukrayins'ko-pol's'ke ekonomichne spivrobitnytstvo $v$ umovakh yevrointehratsiyi [Ukrainian-Polish Economic Cooperation in the Conditions of European Integration]. L'viv: Avers.

4. Mikula, N.A. (2004). Mizhterytorial'ne ta transkordonne spivrobitnytstvo: monohrafiya [Interterritorial and transfrontier cooperation]. L'viv: IRD NAN Ukrayiny.

5. Mikula, N. (2003).Yevrorehiony: dosvid ta perspektyvy [The Euroregions: Experience and Prospects]. L'viv: IRD NAN Ukrayiny.

6. Sholokh, YU.M. (2008). Metodolohiya, orhanizatsiyno-ekonomichnyy mekhanizm stratehichnoho planuvannya $\mathrm{v}$ Karpats'komu rehioni [Methodology, Organizational and Economic Mechanism of Strategic Planning in the Carpathian Region]. Sotsial'no-ekonomichni problemy suchasnoho periodu Ukrayiny. Klastery ta konkurentospromozhnist' prykordonnykh rehioniv, 3 (71), 348.

7. Maksymenko, S. (Eds.). (2000). Rehional'na polityka $v$ krayinakh Yevropy: Uroky dlya Ukrayiny [Regional Policy in Europe: Lessons for Ukraine]. Kyiv: Lohos.

8. Shcherba, H.I., \& Povar, K.V. (2011). Analiz rehional'nykh osoblyvostey investytsiynoyi diyal'nosti [Analysis of regional features of investment activity]. Ekonomichni nauky - Economic sciences (Vols. 1), (pp. 4950). Chernivtsi-Luts'k: CHTEI KNTEU.

9. Dolishniy, M.I. (1997). Rehional'na sotsial'no-ekonomichna polityka (osnovni zasady formuvannya i rozvytku) [Regional socio-economic policy (basic 
principles of formation and development)]. Rehional'na ekonomika - Regional economy, 2, 20-21.

10. Proskurin ,V. (2005). Spetsial'ni ekonomichni zony ta investytsiynyy klimat krayin Tsentral'no-Skhidnoyi Yevropy [Special Economic Zones and the Investment Climate of the Countries of Central and Eastern Europe]. Ekonomichni ese-Economic Essays, 18, 17.

11. Transformatsiya spetsial'nykh ekonomichnykh zon Ukrayiny v konteksti yevropeys'koyi intehratsiyi: al'ternatyvni instrumenty investytsiynoyi ta rehional'noyi polityky (2005) [Transformation of Special Economic Zones of Ukraine in the Context of European Integration: Alternative Tools of Investment and Regional Policy]. L'viv: LF NISD.

12. Mokiy, A.I. (1999). Spetsial'ni (vil'ni) ekonomichni zony yak forma rehional'no-sektoral'noyi modeli zovnishn'oekonomichnoyi intehratsiyi [Special (free) economic zones as a form of regional-sectoral model of foreign economic integration]. Rehional'na ekonomika - Regional economy 4, 110.

13. Blendovski, M. (2005). Spetsial'ni ekonomichni zony Pol'shchi ta yikh vplyv na mistsevyy rozvytok ta investytsiynyy klimat [Special Economic Zones of Poland and their Impact on Local Development and Investment Climate]. Ekonomichni ese - Economic Essays, 18, 22.

14. Hubeni, YU. (2010). Ahenty prykordonnoyi torhivli: pro osoblyvosti biznesu zakhidnoukrayins'kykh "chovnykiv» [Agents of the border trade: on the peculiarities of the business of Western Ukrainian "shuttles"]. Retrieved from : http://www.day.kiev.ua/316269.

15. Mikula, N. Rozvytok transkordonnoho spivrobitnytstva Ukrayiny $v$ umovakh rozshyrenoho YES [Development of cross-border cooperation of Ukraine in the context of the enlarged EU]. Retrieved from: http://niss.lviv.ua/analytics/68.htm.

16. Tymechko, I. Motyvatsiynyy analiz sub"yektiv prykordonnoyi torhivli [Motivational analysis of subjects of border trade]. Retrieved from: http://www.nbuv.gov.ua/portal/soc_gum/en_etei/2009_6_2/25.pdf.

17. Tymechko, I. (2008). Vplyv prykordonnoyi torhivli na rozvytok maloho pidpryyemnytstva [Influence of border trade on the development of small business]. Sotsial'no-ekonomichni problemy suchasnoho periodu Ukrayiny. Klastery ta konkurentospromozhnist' prykordonnykh rehioniv - Socio-economic problems of the modern period of Ukraine. Clusters and Competitiveness of the Border Regions, 3 (71), 342. L'viv: NAN Ukrayiny. In-t rehional'nykh doslidzhen'.

18. Lekh, H.A. Trudova mihratsiya za kordon yak sposib dodatkovoho otrymannya dokhodiv [Labor migration abroad as a way of additional income generation]. Retrieved from: http://www.nbuv.gov.ua/portal /chem_biol/nvnltu /18_4/127_Lech_18_4.pdf.

19. Trudova mihratsiya: plyus - dlya ekonomiky, minus - dlya suspil'stva [Labor migration: plus - for the economy, minus - for the society]. (n.d.). zik.ua. Retrieved from: http://zik.ua/ua/news /2005/01/21/7450 
20. Malynovs'ka, O. A. (2011). Trudova mihratsiya: sotsial'ni naslidky ta shlyakhy reahuvannya [Labor migration: social consequences and ways of responding]. Kyiv : NISD.

21. Nadraha, V. (2011). Trudova mihratsiya: vyklyky dlya Ukrayiny [Labor Migration: Challenges for Ukraine]. Retrieved from: http://dt.ua/ECONOMICS/trudova_migratsiya_vikliki_dlya_ukrayini-75323.html

22. Zhukov, S. \& Chuchka, I. Vdoskonalennya mekhanizmu transkordonnoho ekonomichnoho spivrobitnytstva na marketynhovykh zasadakh [Improving the Mechanism of Cross-Border Economic Cooperation on Marketing Basis].Retrieved from: http://www.univ.rzeszow.pl/nauka/konferencje/ rl_most/ukr/10Zukow_szablon-UKR.pdf

23. Kobylyats'kyy O. Aktual'nist' vykorystannya instrumentiv marketynhu terytoriyi [Relevance of the use of market marketing tools]. Efektyvna ekonomika. Retrieved from: http://www.economy.nayka.com.ua/index.php?operation= $1 \&$ iid $=861$

24. Semiv, L.K. (Eds.). (2007). Rehional'ni suspil'ni systemy [Regional social systems]. L'viv: NAN Ukrayiny; Instytut rehional'nykh doslidzhen'. 